\title{
PENDAMPINGAN PERSIAPAN UJIAN NASIONAL BERBASIS KOMPUTER (UNBK) MTSS NURUL HUDA, DESA SAMPORA, BANTEN
}

\author{
Chendrasari W.O ${ }^{1}$, Christine Natalia ${ }^{2}$, MM. Wahyuni Inderawati ${ }^{3}$ \\ ${ }^{1}$ Program Studi Teknik Industri, Universitas Katolik Indonesia Atma Jaya \\ Email: Chendrasari@gmail.com \\ ${ }^{2}$ Program Studi Teknik Industri, Universitas Katolik Indonesia Atma Jaya \\ Email: chrisnatalia@atmajaya.ac.id \\ ${ }^{3}$ Program Studi Teknik Industri, Universitas Katolik Indonesia Atma Jaya \\ Email: wahyuni.inderawatia@atmajaya.ac.id
}

\begin{abstract}
ABSTRAK
Di Indonesia, salah satu kegiatan penerapan penggunaan jaringan komputer dan internet yang sudah mulai dijalankan oleh pemerintah sejak tahun 2016 adalah kegiatan Ujian Nasional Berbasis Komputer. Hadirnya Ujian Nasional Berbasis Komputer bertujuan agar masyarakat Indonesia mengikuti perkembangan teknologi dan untuk mengurangi penggunaan kertas di Indonesia. Pada kenyataannya, masih banyak sekolah di Indonesia yang belum dapat mengakses komputer dan internet karena masalah keterbatasan tenaga pengajar yang ahli dalam penggunaan komputer, serta keterbatasan dana untuk bisa mendapatkan perangkat komputer yang mampu menunjang kegiatan Ujian Nasional Berbasis Komputer (UNBK). Kegiatan pengabdian masyarakat kali ini dilaksanakan di MTs Nurul Huda yang terletak di Desa Sampora, Banten. Para peserta didik di MTs Nurul Huda, untuk kali pertama akan mulai mengikuti UNBK pada tahun 2019, tetapi sayangnya hal ini belum didukung oleh sarana dan prasarana yang memadai dan penguasaan penggunaan komputer bagi para peserta didik yakni para siswa-siswi. Maka dari itu, kegiatan pengabdian masyarakat yang direncanakan berupa bentuk pengaturan server dan pendampingan dan pelatihan dalam penggunaan komputer dilanjutkan langsung simulasi UNBK bagi para siswa-siswi. Kegiatan persiapan telah dilakukan mulai bulan Desember 2018 sampai dengan pertengahan Januari 2019, sedangkan simulasi dilaksanakan pada 28 - 29 Januari 2019. Kegiatan pengabdian ini sudah tepat dan sejalan dengan kebutuhan dari sekolah MTs Nurul Huda. Hasil dari kegiatan pengabdian ini adalah simulasi UNBK berjalan dengan lancar, hal ini di dukung oleh keberhasilan dalam pengaturan server pada hari sebelumnya dan materi pendampingan kepada para siswa-siswi dalam pengenalan komputer pada sebelum simulasi UNBK berlangsung
\end{abstract}

Kata Kunci: Jaringan Komputer, Ujian Nasional Berbasis Komputer, Simulasi

\section{PENDAHULUAN}

Pada era modern saat ini, pendidikan bukanlah suatu hal yang dapat diabaikan. Pendidikan merupakan wadah proses pembelajaran bagi siswa-siswi untuk dapat mengenali dan mengembangkan potensi diri. Adapun fokus utama dalam memperoleh ilmu pendidikan adalah pada jenjang sekolah. Pendidikan di Indonesia terbagi terbagi atas 3 tingkat yaitu SD, SMP, dan SMA. Semua jenjang dunia pendidikan tidak luput dari integrasi teknologi dalam rangka efisiensi dan efektivitas pembelajaran. Oleh karena itu, untuk mengimbangi teknologi yang semakin pesat ini, terdapat beberapa inovasi baru yang ingin diterapkan dalam dunia pendidikan. Salah satunya adalah proses pengerjaan Ujian Nasional. Ujian Nasional merupakan syarat mutlak bagi seseorang untuk naik dari setiap jenjang pendidikan. Dahulu Ujian Nasional masih memanfaatkan penggunaan kertas dan pensil, namun dengan adanya perkembangan tekonologi media penggunaan kertas mulai bergeser dan berganti menggunakan media teknologi yaitu komputer. Melalui Ujian Nasional Berbasis Komputer digunakan sebagai alat test yang membawa banyak keuntungan, terutama dalam kemudahan administrasi, efektivitas penilaian, dan yang pasti terkait dengan efektivitas biaya. UNBK juga dilihat dapat mencegah kebocoran dan menghindari beragam kecurangan dalam pelaksanaannya, sehingga melalui UNBK dapat diperoleh hasil ujian yang dapat dipercaya.. Selain itu, penggunaan komputer dalam Ujian 
Nasional berperan penting kepada para siswa-siswi untuk merasakan hadirnya kemajuan dan kecanggihan dari sebuah teknologi. Saat ini hampir seluruh pelaksanaan UNBK berbasis online, dasar hukum pelaksanaan UNBK ini tercantum dalam UU Sisdiknas pasal 57 ayat (2) yang menyatakan bahwa mutu pendidikan didasarkan pada evaluasi dilakukan terhadap peserta didik, lembaga dan program pendidikan pada jalur formal dan non formal untuk semua jenjang, satuan dan jenis pendidikan. Pasal 1 ayat (21) menyatakan bahwa evaluasi pendidikan adalah kegiatan pengendalian, penetapan mutu pendidikan terhadap berbagai komponen pendidikan pada setiap jalur, jenjang, dan jenis pendidikan sebagai bentuk pertanggungjawaban penyelenggaraan pendidikan. Guna mengimplementasikan pasal 1 ayat (21), maka pemerintah mengeluarkan permendikbud nomor 57 tahun 2015 tentang Ujian Nasional dan Ujian Sekolah, yang ditindak lanjuti oleh Prosedur Operasi Standar (POS) UN 2017, yang dikeluarkan oleh Badan Standar Nasional Pendidikan (BSNP). Pelaksanan UN pada tahun pelajaran 2016-2017 sebagaiman dijelaskan dalam Bab V POS UN 2017 dengan moda Ujian Nasional Berbasis Komputer (UNBK). Perluasan pelaksanaan UNBK dimaksudkan untuk meningkatkan efisiensi, mutu, reliabilitas, dan integritas ujian. Pemerintah mentargetkan untuk wajib pelaksanaan UNBK pada level pendidikan tingkat SMP/MTs 100\% di tahun 2019 mendatang.

Dunia pendidikan tidak lepas dari kemajuan teknologi, salah satunya adalah komputer. Menurut Sanders (1985), komputer merupakan perangkat elektronik yang bertujuan mengolah data secara tepat dan cepat serta dirancang dan diorganisasikan secara otomatis untuk menerima dan menyimpan data input, mengolah, dan memprosesnya untuk menghasilkan output sesuai dengan instruksi yang telah tersimpan di memori. Sistem pada komputer terbagi ke dalam tiga komponen yaitu software, hardware dan brainware. Komponen-komponen tersebut didefinisikan oleh Ikram (2008). Ikram (2008) menjelaskan bahwa perangkat keras adalah perangkat fisik yang dapat secara langsung dilihat, diraba dan membentuk kesatuan. Bagian dari hardware adalah keyboard, mouse, scanner, motherboard, processor, monitor, dan printer. Sedangkan untuk definisi perangkat lunak adalah komponen komputer yang merupakan kumpulan program dan prosedur yang memungkinkan perangkat keras komputer dapat menjalankan fungsinya sebagai perantara bagi komputer dan pengguna komputer sehingga dapat digunakan. Sedangkan definisi dari Brainware adalah pengguna komputer, yaitu orang yang menangani suatu sistem komputer seperti sistem analisis, programmer, dan komputer operator.

Teknologi didefinisikan sebagai "suatu jaringan komputer yang terdiri dari hardware, software, manajemen data, dan teknologi jaringan informasi" (O'Brein, 2006:28). Penggunaan teknologi sebagai bagian dari kemajuan tekonologi dalam sektor pendidikan, tentunya secara tidak langsung juga menuntut setiap warga sekolah yaitu kepala sekolah, guru, dan para siswa-siswi untuk peka terhadap perkembangan teknologi tersebut. Akan tetapi, pada kenyataannya tidak semua warga sekolah dapat menggunakan komputer, dimana masih dijumpai warga sekolah yang belum dapat menggunakan komputer dan ada sebagian kecil yang sudah bisa tetapi hanya sebatas pada software tertentu pada komputer. Hal ini dirasakan bagi sekolah-sekolah yang tinggal di daerah pinggiran kota dan pedesaan. Hal itu bisa terjadi karena keterbatasan fasilitas komputer yang tersedia maupun keterbatasan pengetahuan mereka akan cara penggunaan komputer yang benar dan optimal sehingga akhirnya sampai saat ini mereka masih menggunakan cara kerja ataupun teknologi yang seadanya. Hal ini jugalah yang menyebabkan terjadinya suatu ketidakseimbangan tingkat pendidikan di dalam kehidupan masyarakat, dimana anak-anak yang tinggal di pinggiran kota ataupun desa jauh lebih tertinggal dibandingkan dengan anak-anak yang menempuh pendidikan di perkotaan. Oleh karena itu, untuk menunjang tingkat pendidikan serta pengetahuan seseorang baik itu guru maupun murid maka diperlukan adanya fasilitas, yakni 
sarana dan prasarana yang memadai bagi mereka untuk belajar serta praktek langsung menggunakan teknologi tersebut. Fasilitas yang dimaksudkan kali ini adalah fasilitas komputer yang memadai agar pada guru dan murid dapat melakukan kegiatan belajar mengajar secara praktek langsung sehingga tuntutan kurikulum pemerintah saat ini pun dapat diikuti oleh seluruh murid yang bersekolah pada jenjangnya masing - masing.

Hal ini sejalan dengan kebutuhan salah satu sekolah yakni Sekolah MTs Nurul Huda yang sampai saat ini belum memiliki fasilitas komputer sebagai faktor pendukung dan penunjang pengajaran. Menurut penjelasan salah satu pendiri Yayasan Nurul Huda Sampora Bapak Idris NS, bahwa berdirinya MTs Nurul Huda Sampora didasari oleh permintaan orang tua siswa MI Nurul Huda Sampora. Maka mulai Juni 2011 dengan dimulai 1 kelas berdiri MTs Nurul Huda Sampora. Karena belum memiliki gedung sendiri maka menggunakan gedung milik MI Nurul Huda Sampora sehingga kegiatan belajar mengajar dilaksanakan pada siang hari. Perlahan tapi pasti jumlah siswa semakin bertambah sehingga kelas pun juga bertambah dari semula 1 kelas menjadi 3 Kelas. Pada Tahun 2013, MTs Nurul Huda menempati gedung sendiri yang berada tidak jauh dari MI Nurul Huda Sampora. Proses belajar mengajarpun dilaksanakan pada pagi hari.

Kegiatan pelaksanaan UNBK pada tahun 2019 akan berlangsung dalam waktu dekat ini, namun sejauh ini sekolah MTs Nurul Huda masih memiliki keterbatasan dalam fasilitas sarana dan prasarana yaitu komputer. Pada tahun 2018, kegiatan Ujian Nasional dilaksanakan masih menggunakan kertas dan pensil, sementara pada tahun 2019 mendatang diwajibkan untuk melaksanakan UNBK. Hal inilah yang menjadi kekuatiran bagi pihak sekolah karena ada keterbatasan sarana dan prasarana komputer, dan dari sisi para siswa-siswi terkait sejauh mana siswa-siswi dapat mengoperasikan komputer. Sejauh ini, belum ada implementasi praktek dengan menggunakan komputer yang di sekolah. Kedua hal itulah yang menjadi tantangan dalam menghadapi UNBK pada tahun 2019.

Untuk menjawab permasalahan dan sejalan dengan kebutuhan oleh Sekolah MTs Nurul Huda, maka ada kerjasama antara pihak sekolah MTs Nurul Huda dengan Fakultas Teknik Unika Atma Jaya untuk mengadakan kegiatan pengabdian kepada masyarakat yang selalu berupaya memberikan kontribusi bagi pengembangan dunia pendidikan di Desa Sampora khususnya di Sekolah MTs Nurul Huda. Tujuan dari kegiatan pengabdian masyarakat ini untuk pendampingan bagi para guru dan siswa-siswi di MTs Nurul Huda Desa Sampora untuk mengerti secara langsung mengenai perkembangan teknologi terutama dalam penggunaan komputer sebagai persiapan pembekalan bagi para murid di MTs Nurul Huda Sampora untuk mengikuti Ujian Nasional Berbasis Komputer (UNBK). Bentuk aktivitas yang dilakukan antara lain pengaturan server, pengenalan dan penguasaan penggunaan komputer kepada para siswa-siswi, dan simulasi UNBK.

\section{METODE PELAKSANAAN PKM}

Kegiatan pengabdian kepada masyarakat pendampingan untuk persiapan Ujian Nasional Berbasis Komputer (UNBK) pada MTs Nurul Huda Sampora, Banten ini dilaksanakan pada tanggal 21 - 26 Januari 2019 dengan kegiatan berupa pengaturan server dan instalasi perangkat lunak Exambro, serta pada tanggal 28 - 29 Januari 2019 untuk melaksanakan simulasi. Mitra dari MTs Nurul Huda Sampora terdiri dari Bapak Engkay selaku Kepala Sekolah, 4 orang Guru (Bapak Indra, Bapak Jep Lesmana, Bapak Rusman dan bapak Tarmuji) dan 49 siswa-siswi MTs 
Nurul Huda Sampora. Kegiatan tahap pertama yang dilakukan adalah mempersiapkan program UNBK pada fasilitas komputer server dan client. Hasil dari tahap ini adalah tersambungnya seluruh komputer client dan berhasilnya koneksi dengan server lokal maupun server pusat (gambar 1,2,dan 3).

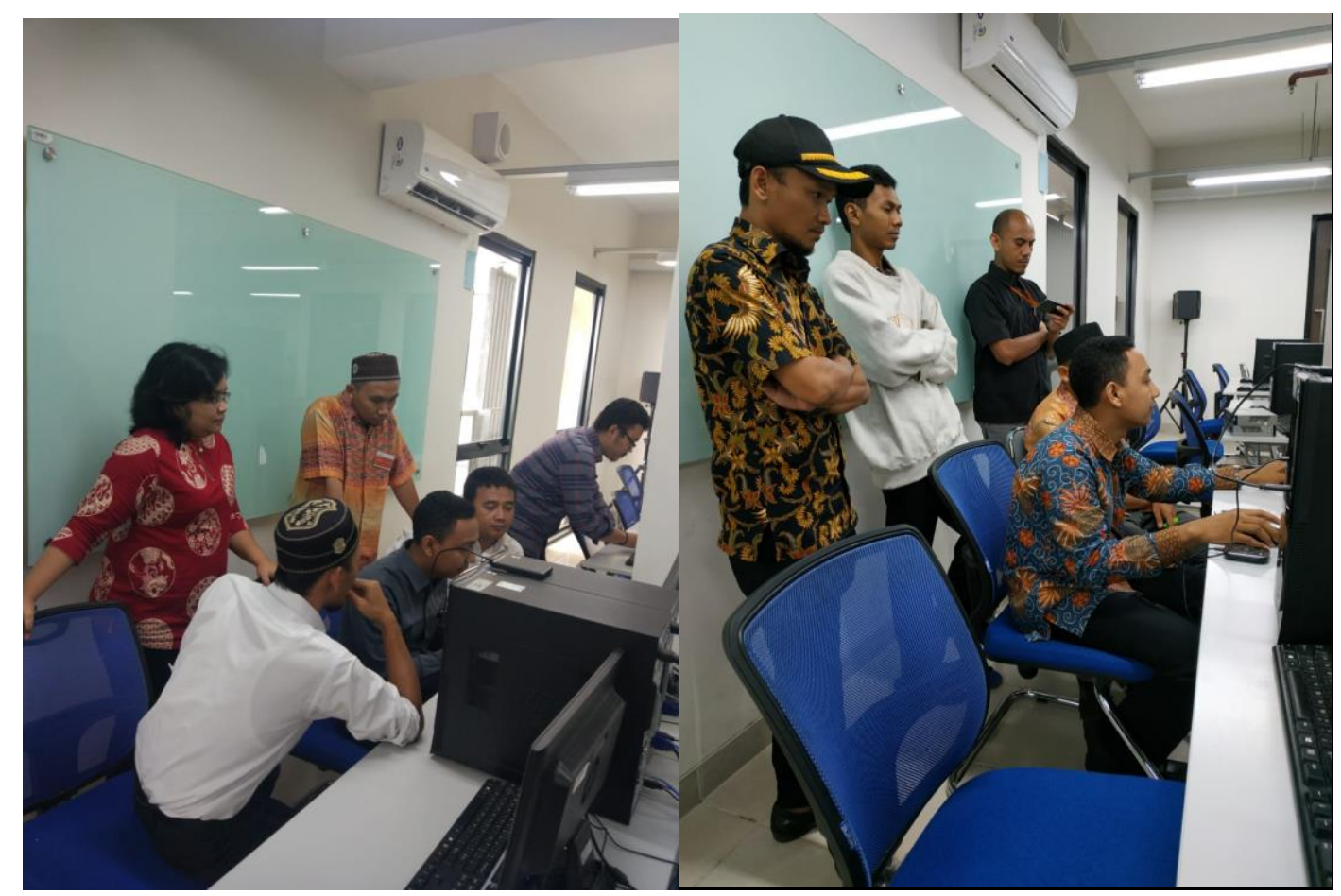

Gambar 1. Kegiatan mempersiapkan program UNBK

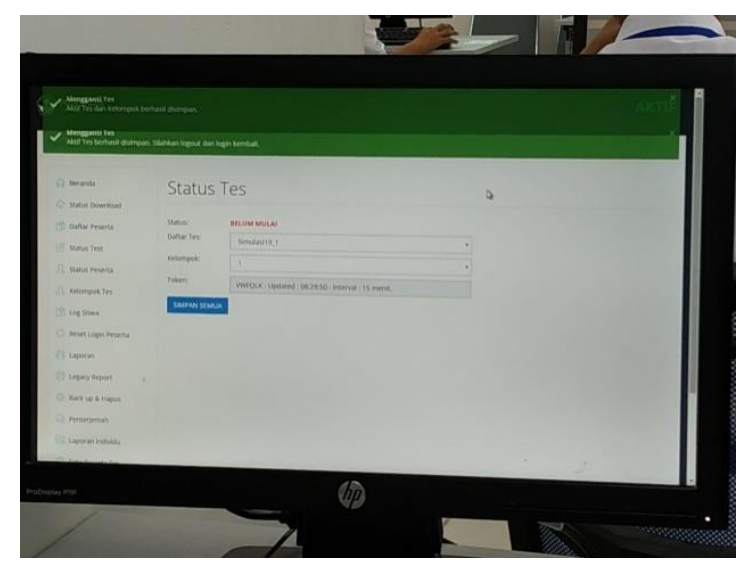

Gambar 2. Tampilan dari keberhasilan konektivitas UNBK 


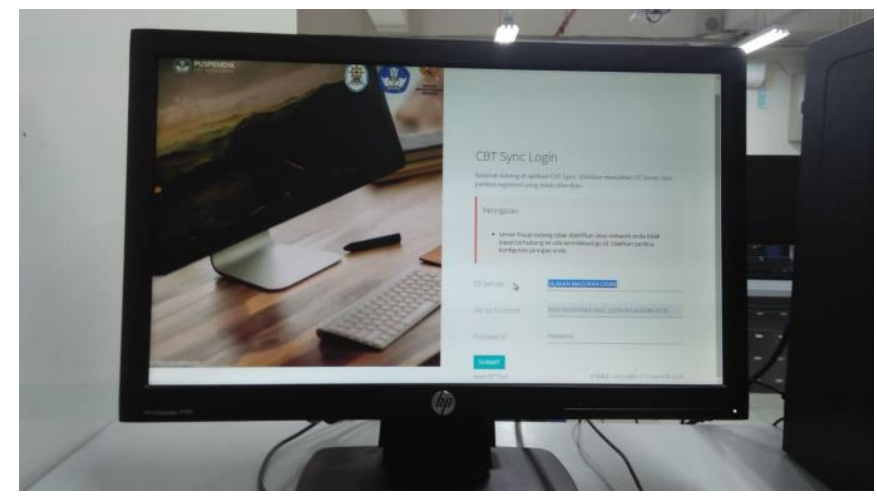

Gambar 3. Tampilan berhasilnya koneksi dengan jaringan lokal maupun server pusat.

Sistem UNBK yang dilaksanakan saat ini adalah Semi On-line UNBK, dimana terminal ujian dilayani oleh server lokal serta soal dan hasil ujian dikirim melalui jaringan internet (sinkronisasi). Selanjutnya, dilakukan sebelum dilakukan pelaksanan simulasi UNBK perlu dilakukan proses pendampingan kepada 49 siswa-siswi mengoperasikan komputer menggunakan mouse dan keyboard. Proses pendampingan dan pelatihan ini dilakukan secara singkat yaitu kurun waktu 2 jam kepada 49 siswa-siswi. Pendampingan dan pelatihan ini, tim usulkan setelah hasil diskusi sebelumnya. Hal ini perlu dilakukan karena ini kali pertamanya para siswa/i sekolah MTs Nurul Huda melakukan UN berbasis Komputer. Dengan UN berbasis komputer harus didukung oleh penguasaan penggunaan komputer oleh para siswa-siswinya.

Berdasarkan hasil pelatihan dan pendampingan ini pada gambar 4, para siswa-siswi sangat antusias mengikuti pelatihan dan pendampingan ini. Hal ini bisa terlihat di saat pemateri mengenalkan fitur-fitur di komputer yang sebelumnya mereka tidak memahami, dan pemateri bertanya kepada para siswa/i sejauh mana mereka menguasai pengunaan komputer dan mengenali fitur-fitur ini, dan diperoleh hanya sedikit yang menguasai komputer. Oleh karena, pelaksanaan pelatihan dan pendampingan penguasaan penggunaan komputer sangat tepat sesuai dengan kebutuhan peserta saat ini yang berkaitan dengan pelaksanaan UNBK.

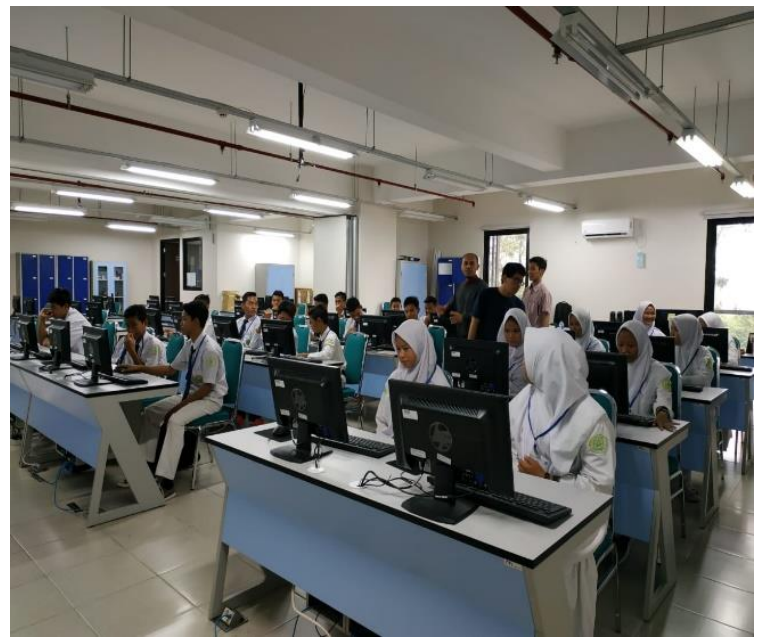

Gambar 4. Pelatihan dan Pendampingan Penguasaan Penggunaan Komputer

Langkah berikutnya, dilakukan uji coba Sistem Ujian pada Jaringan Komputer dalam bentuk simulasi UNBK bagi murid-murid MTsS Nurul Huda. Kegiatan ini berjalan lancar dan sukses (gambar 5). 


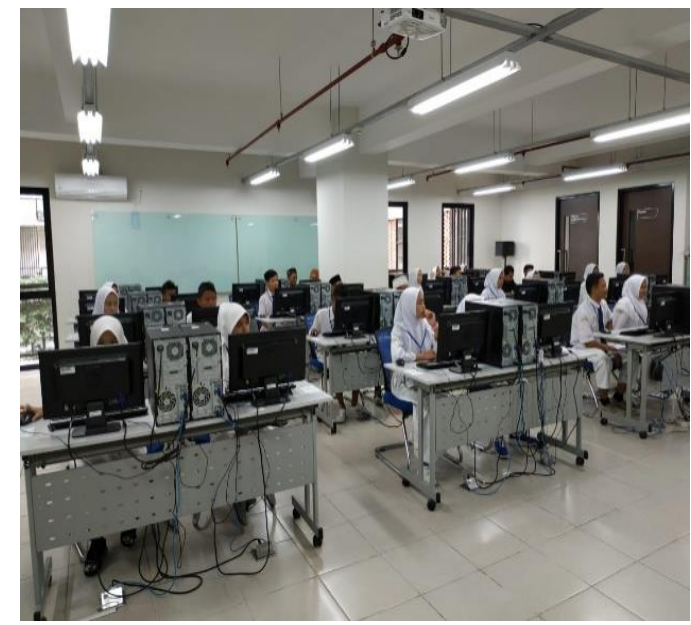

Gambar 5. Simulasi UNBK.

\section{HASIL DAN PEMBAHASAN}

Dalam pelaksanaan simulasi UNBK kali ini, pada tahap awal ini dilakukan kegiatan pemasangan server dan jaringan komputer sebagai bagian dari pelaksanaan kegiatan pengabdian masyarakat untuk simulasi UNBK yang diselenggarkan pada tanggal 21-26 Januari 2019 yang dihadiri oleh Mitra dari MTs Nurul Huda Sampora terdiri dari Bapak Engkay selaku Kepala Sekolah, 4 orang Guru (Bapak Indra, Bapak Jep Lesmana, Bapak Rusman dan bapak Tarmuji). Setelah pengaturan server dan jaringan telah selesai dengan baik, maka selanjutnya bisa dilakukan simulasi UNBK sesuai jadwal mata pelajaran yang telah ditentukan.

Pengenalan dan pelatihan komputer dan simulasi UNBK diikuti oleh 49 peserta siswa-siswi SMP MTs Nurul Huda yang saat ini berada di kelas IX. Berdasarkan hasil pendampingan dan pengenalan komputer ini disambut dengan antusias oleh para siswa-siswi, karena dengan adanya pengenalan komputer ini merupakan pengalaman pertama kali mengetahui bentuk fisik komputer dan mengenal fitur-fitur di dalam komputer seperti terlihat pada gambar 5. Oleh karena, pelaksanaan pelatihan dan pendampingan penguasaan penggunaan komputer sangat tepat sesuai dengan kebutuhan peserta saat ini yang berkaitan dengan pelaksanaan UNBK.

Setelah dirasakan para siswa/i sudah cukup memahami fitur-fitur di komputer, dan cara mengoperasikan komputer dengan mouse dan keyboard, maka selanjutnya dilakukan simulasi UNBK dengan mata pelajaran matematika seperti terlihat pada gamabr 8 . Hambatan terkait pengoperasian komputer di saat simulasi hampir tidak ada, hal ini dapat dilihat ketika sebelum mereka mengerjakan soal ujian, mereka diminta untuk mengisi nomer token dan password untuk mengisinya para peserta dituntut menggunakan mouse untuk mencari menu username dan password yang diminta dan setelah itu, peserta diminta untuk memilih dan menekan angka/huruf pada keyboard komputer, hasilnya mereka semua mampu melewatinya dan dilanjutkan simulasi UNBK yang berlangsung 2 jam dengan mata pelajaran matematika. 


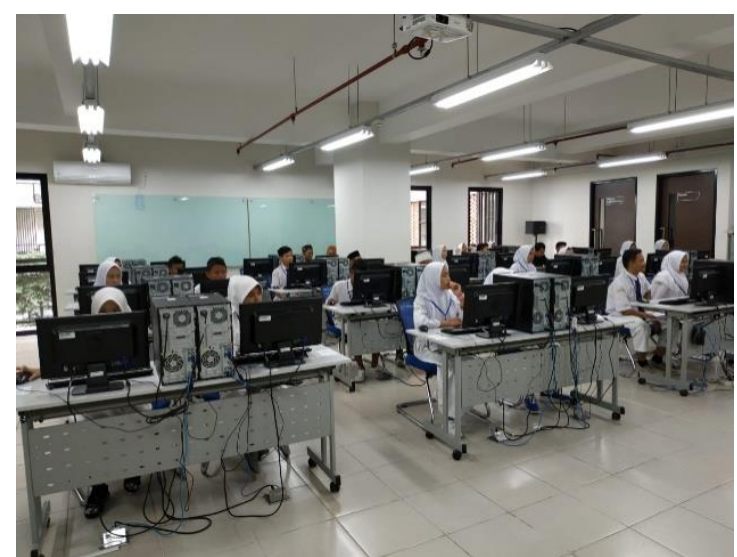

Gambar 6. Simulasi Pengerjaan Soal UNBK Mata Pelajaran Matematika

\section{KESIMPULAN}

Berdasarkan kegiatan pelaksanaan pengabdian kepada masyarakat dapat disimpulkan bahwa untuk mendukung kelancaran UNBK ke depannya, maka diperlukan materi TIK dan fasilitas sarana dan prasarana seperti komputer dan laboratorium komputer di sekolah khususnya di MTs Nurul Huda. Tujuannya untuk mengenalkan secara dini tentang komputer dan pemanfaatannya dalam pembelajaran sehingga ke depannya kegiatan UNBK pada tahun selanjunya dapat berjalan dengan lancar. Dan sebagai evaluasi terhadap keberlanjutan program PKM ini maka dapat diidentifikasi beberapa usulan program pengabdian masyarakat kepada mitra MTs Nurul Huda antara lain pelatihan konsep Computer Based Testing (CBT), pengenalan dan pelatihan aplikasi perangkat lunak CBT serta pelatihan topologi konfigurasi jaringan komputer untuk CBT.

\section{DAFTAR PUSTAKA}

A, O’Brien. (2006). Introducing To Information System, Salemba Empat, Jakarta

BSNP. (2015). Prosedur Operasional Standar Penyelenggaraan Ujian Nasional Nomor 0031/P/BSNP/III/2015 Depdiknas.(2003). Undang-Undnag RI No.20 tahun 2003 tentang sistem pendidikan nasional.

Ikram,A.(2008)."Beraksara dalam kelisanan” dalam Metodologi Kajian Tradisi Lisan, Pudentia MPSS, ed 2008. Jakarta: Asosias Tradisi Lisan.

Sanders, D.H. (1985). Computer Today. McGraw-Hill, New York 